\title{
An Estimation of Inflation Threshold for Africa
}

High and unpredictable inflation rates are harmful to any economy, as they increase inefficiencies in the market, render companies incapable of planning long-term, and compel investors to transfer resources from high- to low-inflation economies as a hedge against rising costs of inflation, as has happened in the past in Zimbabwe, and presently in Nigeria and South Africa (Kelikume and Evans, 2015; Debaere and Debaere, 2017).

Inflation is considered by many economists to affect an economy in both negative and positive ways (Kremer, Bick and Nautz, 2013; Eggoh and Khan, 2014; Ball, 2017; Nas and Perry, 2018; Evans, 2018). The negative effects of inflation include uncertainty over future inflation which may depress savings and investment; lead to increase in the opportunity cost of holding money; and engender shortages of goods as consumers begin hoarding out of concern that prices will rise in the future (Kremer et al., 2013; Vinayagathasan, 2013; Nas and Perry, 2018). These negative effects can be called "the heating effects" of 
inflation. The positive effects include reducing unemployment due to nominal wage rigidity; reducing the real burden of private and public debt; and keeping nominal interest rates above zero so that central banks can regulate interest rates to stabilize the economy. These positive effects can be referred to as "the cooling effects" of inflation. The heating effects of inflation on the economy on one hand and the cooling effects on the other leads to non-linearity and, consequently, an inflation threshold at which inflation turns from cooling to heating; that is, a threshold at which inflation becomes inimical to growth (Kremer et al., 2013).

The quantity theory and the Keynesian model of aggregate demand (AD) and aggregate supply (AS) curves establish that changes in inflation transmits to GDP growth. There has been extensive debate in the literature on the nature of this inflation-growth nexus (e.g., Khan and Senhadji, 2001; Blanchard, DellAricia and Mauro, 2010; Kremer et al., 2013; Evans, 2018). Existing studies have claimed that there is a threshold at which inflation becomes detrimental to growth (e.g., Khan and Senhadji, 2001; Blanchard et al., 2010; Kremer et al., 2013). Also in Africa, many cross-country and panel data studies have found different inflation thresholds in different parts of the continent even after accounting for other determinants of growth, unobserved country-specific effects on the inflation-growth nexus, potential simultaneity biases and omitted variables (e.g., Nkume and Ngalawa, 2014; Yabu and Kessy, 2015; Ndou and Gumata, 2017). The results of these studies are, however, at best ambiguous. Moreover, there is a particular concern: the small samples typically used may significantly lead to flawed conclusions. The present paper addresses this flaw by using a large sample of 41 African countries.

Further, movements in resource prices have complicated the jobs of policymakers and business leaders over the past four decades. For example, "increases in inflation during the 1970's have been blamed, in part, upon rapid increases in petroleum prices. The long decline in inflation during the 1980's and 1990's has in turn been associated with declines in oil prices" (LeBlanc and Chinn, 2004, p. 3). Hence, a clear understanding of the empirical linkage between inflation and long-term growth in resource rich and nonresource rich African countries will be key to the proper conduct of inflation targeting in the continent. Therefore, the sample of African countries in this study is divided into 21 resource rich countries and 20 nonresource rich countries in order to see if there are any differences in the empirical linkage between inflation 


\section{Kelikume}

and long-term growth in the two samples. To the best of author's knowledge, no other study in the literature has attempted this for Africa.

Therefore, the objective of this study is to determine the linkage between inflation and long-term growth by looking at resource rich and non-resource rich African countries, and further determine the inflation threshold for economic growth in the continent. The rest of this paper is organized as follows. Next section presents theory and literature review. Third section describes the data, the model and the estimation methods. Fourth section provides empirical results. Last section provided conclusion of the study.

\section{LITERATURE REVIEW}

The quantity theory and monetarism emphasize the crucial role of monetary growth in determining inflation (Uysal, 2016; Friedman, 2017). In the short-run, money affects real variables like price level, employment and real GDP; in the long-run, the effects are on the price level and nominal variables (Evans, 2018). In the short-run, the Philips Curve which theorizes the inflation-unemployment trade-off holds. In the long-run, money is neutral and super-neutral (Tobin, 1965; Rossouw and Marais, 2018). Thus, the monetary economists suggest that, in the long-run, inflation affects only prices, but not growth (Evans, 2018).

In the Keynesian model, the AS curve is upward sloping in the short-run so that a change in AD affects both price and output. Dornbusch, Fisher and Kearney (1996) argues that AD and AS have an adjustment path which gives an initial positive relationship between inflation and growth but turns negative in the later part of the adjustment path. The initial positive relationship between inflation and economic growth is attributable to the time inconsistency problem where producers believe that only their prices have increased while the other prices remain the same. Thus, the relationship between inflation and growth is positive as the time inconsistency problem lures the producers into more output. Likewise, Blanchard and Kiyotaki (1987) argue that the relationship between inflation and economic growth is positive because of firms' collusion to supply on agreed price, leading the firm to produce even at higher price.

Changes in inflation transmit to real GDP growth in a process that can be referred to as "inflation-growth transmission mechanism" (see Figure 1). High and volatile unanticipated inflation creates uncertainty 
(Kelikume and Evans, 2015) which affects the rate of return on capital and investment (Pindiky and Solimano 1993), and undermines domestic and foreign investors' confidence about future monetary policy. This channel of influence whereby inflation hurts the accumulation of capital is referred to as the accumulation or investment effect of inflation on growth. Another channel is the efficiency channe/ where inflation worsens the long-term performance of an economy by reducing the total factor productivity (Yabu and Kessy, 2015).

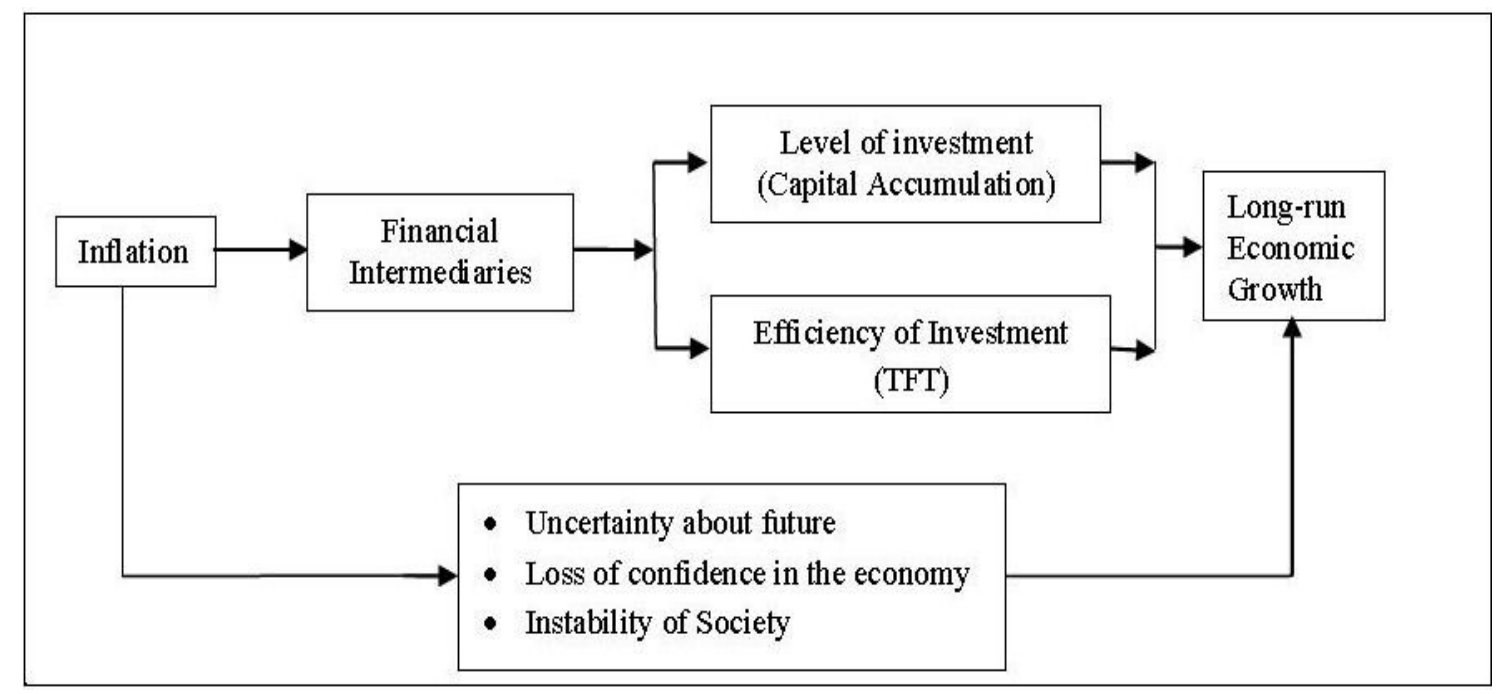

Source: $\operatorname{Li}(2006)$

Figure 1. Transmission Mechanism from Inflation to Growth

The empirical evidences on the inflation-growth nexus differ across countries, subject to country experiences, methodology and data periods. In a seminal study, Bhatia (1960), using a linear model for Sweden, Canada, United Kingdom, Germany, and Japan from 1812 to 1912, showed that growth was inversely related to inflation in Japan and Germany; higher rates of growth were accompanied by higher rates of inflation in the Sweden, Canada and United Kingdom. However, after the severe, high and persistent inflation rates associated with macroeconomic decline in 1970s and 1980s, attention was given and several studies were dedicated to unravel this inflation-growth nexus. For example, Barro (1995), using the instrumental variable method for a five-year average data of a sample of 100 countries from 1960 to 1990, obtained robust evidence that a 10 percent increase in inflation slows the growth rate of the real GDP per capita by 0.2 to 0.3 percentage points. 


\section{Kelikume}

In the 1990s, different studies went farther than estimating the existing relationship between inflation and growth to identify the threshold level at which inflation is detrimental to economic growth. Studies such as Bruno and Easterly $(1995 ; 1998)$ started providing further facts about the threshold level at which the relationship between inflation and the economy becomes negative. They inferred that the inflation-economic growth linkage is non-linear and, therefore, has a threshold level. However, the empirical literature on the threshold level of inflation differs considerably across countries. For example, Khan and Senhadji (2001), using a panel of 140 industrial and developing countries, found the existence of statistically significant thresholds of 11-12 percent and 1-3 percent inflation levels for developing and industrialized countries, respectively. Gillman, Harris and Matyas (2002), using two samples of OECD and APEC countries from 1961 to 1997 , found that when inflation rate goes from $0-10$ percent range to a $0-5$ percent range, the negative co-efficient almost doubles and is highly significant. Pollin and Zhu (2005), using a non-linear quadratic model for 80 countries from 1961 to 2000 , found a threshold inflation in the range of $15-23$ percent for low-income countries and 14-16 percent for middle-income countries. Blanchard, et al., (2010) argues that an inflation target of 4 percent is appropriate for industrial countries because it gives ample room for expansionary monetary policy during adverse shocks. This position however contradict the findings of Goncalves and Salles (2008) where available evidence from their study on a group of developed economies shows adopting an inflation targeting regime (IT) was instrumental in bringing inflation and inflation volatility down. Espinoza, Hyginus and Ananthakrishnan (2010), using a smooth transition model for a panel of 165 countries from 1960 to 2007, found a 10 percent threshold level of inflation for GDP growth.

The empirical literature on the threshold level of inflation differs across emerging markets. Sweidan (2004), in a study of the Jordanian economy using a non-linear model, found an inflation threshold of 2 percent, and that the impact of inflation on growth is more significant than the impacts of inflation on uncertainty and variability. Gokal and Hanif (2004), in a study of the Fijian economy, show that a weak negative correlation exists between inflation and growth, and the causality runs one-way from growth to inflation. Hussain (2005), using Khan and Senhadji (2001) and Singh and Kaliappa (2003) technique for Pakistan, found no definite threshold level of inflation, though he suggested a 4 to 6 percent range of 
inflation as appropriate for the economy. Ahmed and Mortaza (2005), using a non-linear approach for Bangladesh economy, found a statistically significant long-run negative relationship between inflation and economic growth, and an inflation threshold of 6 percent. Munir et al. (2009), using an endogenous threshold autoregressive model for the Malaysian economy from 1970 to 2005, found an inflation threshold of 3.89 percent and that below this threshold level, a statistically significant positive relationship exists between inflation and growth.

Also, the literature on the threshold level of inflation differs across African countries. Nell (2000), applying the VAR technique on South African's data for 1960 to 1999 , suggest that single-digit inflation may be beneficial to growth, while double digit may slow growth. Frimpong and Oteng-Abayie (2010), using threshold regression models for the Ghanaian economy from 1960 to 2008, found an inflation threshold of 11 percent and that above the 11 percent level, inflation adversely affects economic activities. Salami and Kelikume (2010), using a non-linear inflation-growth model, found an inflation threshold of 8 percent for Nigeria over the period 1970-2008. Also Rutayisire (2013), using a quadratic regression model for the Rwandan economy from 1968 to 2010, found an inflation threshold of 14.97 percent.

Yabu and Kessy (2015), using a non-linear quadratic model, empirically estimated the threshold level of inflation for Kenya, Tanzania and Uganda for the period 1970 to 2013. Besides showing that credit to GDP ratio, foreign direct investment flows and degree of openness of the economy have significant and positive impacts on growth. Yabu and Kessy (2015) establish that any rate of inflation beyond 8.46 percent has significantly negative impact on economic growth: the optimal levels of inflation for Kenya, Uganda and Tanzania are 6.77 percent, 8.41 percent and 8.80 percent, respectively, beyond which inflation becomes detrimental to economic growth.

Summarily, a large and expanding literature has tried to shed light on the empirical relation between inflation and economic growth (e.g., Khan and Senhadji, 2001; Blanchard et al., 2010; Kremer et al., 2013; Evans, 2018). Much of this literature has largely focused on the marginal effects of inflation on growth, the non-linear inflation-growth nexus, and the threshold levels at which inflation becomes inimical to growth. Among these, in recent times, the determination of inflation thresholds has received substantial attention 


\section{Kelikume}

(e.g., Khan and Senhadji, 2001; Blanchard et al., 2010; Kremer et al., 2013; Ndou and Gumata, 2017).

From the theories and the review of literature, several observations can be highlighted. Firstly, the quantity theory and the Keynesian model of $A S$ and $A D$ establish that changes in inflation transmits to GDP growth. However, there has been extensive debate in the literature on the nature of this inflation-growth nexus. In fact, some of the studies have claimed that there is a threshold at which inflation becomes detrimental to growth. Many studies have investigated the empirical relations between inflation and growth in Africa, the results are however at best ambiguous. Moreover, there is a particular concern: the small samples typically used may significantly lead to flawed conclusions. The present paper addresses that flaw by using a large sample of 41 African countries. This study further expands the literature in another context: because of the concern for movements in resource prices, the sample of African countries in this study is divided into resource rich and non-resource rich African countries in order to explore the differences in the linkage between inflation and long-term growth in the continent.

\section{METHODOLOGY}

This study employs an unbalanced panel-data set of 41 African countries. The sample covers the period 1960-2015 and was collected from (World Bank Indicator, 2017).World Bank collection of development indicators is compiled from officially-recognized international sources. The database provides the most current and accurate global development data available, and includes national, regional and global estimates.

In this study, the choice of 21 countries as resource rich and 20 as non-resource rich was based on Ghura and Pattillo's (2012) classification. Ghura and Pattillo (2012) defined a country as 'resource-rich', if exports of non-renewable natural resources (i.e., oil, minerals and metals) constitute more than 25 percent of the country's total exports. The resource rich countries in Africa are Algeria, Botswana, Burundi, Cameroon, Central African Republic, Chad, Egypt, Equatorial Guinea, Gabon, Ghana, Mali, Morocco, Namibia, Nigeria, Sierra Leone, South Africa, Sudan, Tanzania, Tunisia, Zambia and Zimbabwe. The non-resource rich countries are Benin, Burkina Faso, Cape Verde, Congo, Cote d'Ivoire, Ethiopia, Gambia, Guinea-Bissau, 
Kenya, Lesotho, Malawi, Mauritania, Mozambique, Niger, Rwanda, Senegal, Swaziland, Togo, Trinidad \& Tobago and Uganda (see Table 1, Appendix-I).

In any empirical analysis of the effects of inflation on economic growth, it is important to control for the impact of other economic variables which may be correlated with inflation. Following the empirical literature such as Khan and Senhadji (2001), David, Pedro and Paula (2005) and Kremer et al. (2013), the control variables considered in this study were the initial income level (INITIAL) computed as lagged GDP per capita; the percentage of GDP devoted to investment (/GDP); the annual percentage change in the terms of trade (DTOT) computed as exports divided by imports; openness (OPEM) computed as the logged share of exports plus imports in GDP; the growth rate of population (DPOP); and the standard deviations of openness (SDOPEN) and the terms of trade (SDTOT) (see Table 2, Appendix-II).

Inflation has been lower in Africa with an average annual inflation rate of 17.9 percent over the sample period, compared to 33.63 percent for non-industrialized countries found by Kremer et al. (2013). For the sample of African countries, the dispersion of inflation rates was too high. As a result, this study employs logged inflation rates so that the regression results are not distorted by outliers (see Ghosh and Phillips, 1998). According to Kremer et al. (2013, p. 7), "using logged inflation rates has the plausible implication that multiplicative, not additive, inflation shocks will have identical growth effects". Our sample has negative inflation rates; therefore we follow David et al. (2005), Khan and Senhadji (2001) and Kremer et al. (2013) and employed a semi-log transformation of the inflation rate $\eta_{i t}$.

$$
\eta_{i t}= \begin{cases}\eta_{i t}-1, & \text { if } \eta_{i t} \leq 1 \\ \ln \left(\eta_{i t}\right), & \text { if } \eta_{i t}>1\end{cases}
$$

Where, inflation rates less than one are re-scaled for continuity. Compared to the raw inflation data, the distributions of the semi-logged inflation rates were more symmetric and consistent with the normal distribution (Kremer et al., 2013).

Most of the recent literature dealing with inflation thresholds used the panel threshold model introduced by Hansen (1999) which estimates the inflation thresholds instead of imposing them a priori. This method has some drawbacks: all regressors are required to be exogenous, leading to a potential endogeneity bias. 


\section{Kelikume}

Studies such as Khan and Senhadji (2001), Cuaresma and Silgoner (2004) and Foster (2006) ignored this potential endogeneity bias in their regressions. This flaw can lead to biased estimates of the inflation thresholds and to misleading conclusions on the effects of inflation on growth in the corresponding inflation regimes (Kremer et al., 2013). In this study, in order to remove the endogeneity bias, we adopt the dynamic panel threshold model used by Kremer et al. (2013) in their analysis on the impact of inflation on growth for industrialized and non-industrialized countries. Kremer et al. (2013), using Arellano and Bover's (1995) forward orthogonal deviations transformation, combine Caner and Hansen's (2004) instrumental variable estimation of the cross-sectional threshold model with Hansen's (1999) panel threshold model. In the Kremer et al.'s (2013) dynamic model, the endogeneity of the main control variables of economic growth poses no issue in the estimation of the threshold level of inflation.

In the following empirical application, we applied Kremer et al.'s (2013) dynamic panel threshold model to the analysis of the impact of inflation on long-term economic growth in Africa. In line with Kremer et al. (2013), consider the following threshold model of the inflation-growth nexus:

$$
D G D P_{i t}=\theta_{i}+\alpha_{1} \bar{\eta}_{i t} I\left(\bar{\eta}_{i t} \leq \tau\right)+\beta_{1} I\left(\bar{\eta}_{i t} \leq \tau\right)+\alpha_{1} \bar{\eta}_{i t} I\left(\bar{\eta}_{i t}>\tau\right)+\rho x_{i t}+\xi_{i t}(2)
$$

Where $\bar{\eta}_{i t}$ is both the threshold inflation variable and the regime-dependent regressor; $x_{i t}$ is the vector of endogenous control variables.

\section{RESULTS}

Dynamic panel estimates are only valid when the variables are $I(0)$ and $I(1)$. Before proceeding to the threshold estimation therefore, we need to verify that all the variables were $I(0)$ and $I(1)$. Im, Pesaran and Shin W-stat, ADF-Fisher Chi-square and PP-Fisher Chi-square were used to determine the order of integration of the variables. The three panel unit root results showed that the variables were a mix of $I(0)$ and $\mathrm{I}(1)$, meaning that all the series were stationary in their first differences. Summarily, the variables were either $\mathrm{I}(0)$ or I(1), thus indicating that it is appropriate to apply the dynamic panel methodology (see Table 3).

Table 4 (see Appendix-III) shows the results obtained for the full sample, the resource rich and nonresource rich countries. While the upper part of the table shows the inflation threshold estimates and the 


\begin{tabular}{ccccccc}
\hline & \multicolumn{2}{c}{ IPS W-Stat } & \multicolumn{2}{c}{ ADF-Fisher } & \multicolumn{2}{c}{ PP-Fisher } \\
& $\mathrm{I}(0)$ & $\mathrm{I}(1)$ & $\mathrm{I}(0)$ & $\mathrm{I}(1)$ & $\mathrm{I}(0)$ & $\mathrm{I}(1)$ \\
\hline$D G D P_{i t}$ & $-1.921^{* *}$ & $-2.285^{*}$ & $48.192^{* *}$ & $59.398^{*}$ & $49.514^{* *}$ & $105.094^{*}$ \\
$\eta_{i t}$ & $-1.934 * *$ & $-2.059^{*}$ & 35.450 & $52.593^{*}$ & $58.736^{* *}$ & $90.273^{*}$ \\
$I N I T I A L_{i t}$ & -1.608 & $-1.920^{* *}$ & 37.079 & $58.621^{*}$ & 25.008 & $44.43^{* *}$ \\
$I G D P_{i t}$ & -1.691 & $-1.994^{* *}$ & 36.145 & $53.117^{*}$ & 23.089 & $51.148^{*}$ \\
DPOP $_{i t}$ & $-2.038^{*}$ & $-2.696^{*}$ & $54.973^{*}$ & $59.966^{*}$ & $69.351^{*}$ & $82.2711^{*}$ \\
DTOT $_{i t}$ & $-1.923^{* *}$ & $-2.482^{*}$ & 35.951 & $52.229^{*}$ & $55.675^{* *}$ & $78.020^{*}$ \\
SDTOT & 0.453 & $-2.389^{*}$ & 23.960 & $55.321^{*}$ & 53.619 & $177.681^{*}$ \\
OPEN & 0.524 & $-3.605^{*}$ & 24.559 & $57.119^{*}$ & $41.488^{* *}$ & $59.937^{*}$ \\
SDOPEN $_{\text {it }}$ & $-1.939^{* *}$ & $-2.648^{*}$ & $42.747^{* *}$ & $55.734^{*}$ & $52.319^{* *}$ & $95.363^{*}$ \\
\hline Notes: * and $* *$ denotes significance at 1\% and 5\% levels. Probabilities for Fisher tests are computed using an asymptotic Chi-square \\
distribution. IPS assumes asymptotic normality.
\end{tabular}

\section{Table 3. Panel Unit Root Tests}

95 percent confidence interval, the middle part displays the regime-dependent inflation-growth coefficients. In detail, $\hat{\alpha}_{1}$ and $\hat{\alpha}_{2}$ denote the marginal inflation effects on growth in the low- and high-inflation regimes, specifically when inflation is below and above the inflation threshold. The lower part of the table displays the coefficients of the control variables.

The Empirical Relation between Inflation and Growth in the Full Sample of African countries

The second column of Table 4 shows the results for the full sample of all African countries. The estimated inflation threshold is 11.1 percent. The 95 percent confi dence interval ranges from 6.39 percent to 15.02 percent. The inflation coefficient for the low-inflation regime $\left(\hat{\alpha}_{1}=1.22\right)$ is positive but insignificant. The coefficient of inflation for the high-inflation regime $\left(\hat{\alpha}_{2}=-0.88\right)$ is significantly negative when inflation exceeds its threshold value.

\section{The Empirical Relation between Inflation and Growth in Resource-Rich Countries}

The third column of Table 4 shows the results of the empirical relationship between inflation and growth in resource-rich countries. The two regime-dependent coefficients of inflation are plausibly signed and significant. $\hat{\alpha}_{1}=1.19$ shows that inflation is beneficial for growth in resource-rich countries when inflation is below its threshold value. However, when inflation exceeds its threshold, it has a negative effect $\left(\hat{\alpha}_{2}=-0.48\right)$ on growth.

\section{The Empirical Relation between Inflation and Growth in non-resource rich African countries}

The fourth column of Table 4 shows the results for non-resource rich countries. They are different from 


\section{Kelikume}

resource-rich countries estimates in two respects. First, the estimated inflation threshold value $(9.4 \%)$ is certainly less than in resource rich countries, with the 95 percent confidence interval ranging between 6.65 percent and 11.19 percent. The coefficient of inflation $\left(\hat{\alpha}_{2}=-0.51\right)$ is significantly negative when inflation exceeds its threshold value.

Impact of Covariates

The coefficients of the covariates are plausibly signed, consistent with the theoretical predictions. Notably, the estimates of INITIAL, OPEN and SDOPEN are statistically significant in the full, resource-rich and nonresource rich samples. In line with the neo-classical growth model, the estimates of /GDP is statistically significant and positive for the full sample of African countries and non-resource rich countries.

\section{DISCUSSION}

For the full sample of all African countries, this study has shown that the estimated inflation threshold is 11.1 percent. The 95 percent confidence interval ranging from 6.39 percent to 15.02 percent shows that the critical value of inflation for African countries is evidently less than, for example, the 17 percent proposed by Kremer et al. (2013) for non-industrialized countries. In other words, inflation rates above even 6.4 percent may already be too high. The inflation coefficient for the low-inflation regime is positive but insignificant, meaning that when inflation gets below this threshold value, there tends to be some growth-augmenting effects of inflation. The coefficient of inflation for the high-inflation regime is significantly negative when inflation exceeds the threshold value, meaning there is growth-stifling effect of high inflation beyond this threshold for African countries.

Also, for the resource-rich countries, this study has shown that inflation is beneficial for growth when inflation is below its threshold value. For example, if inflation rates increase from 0 to 1 percent, long-term growth increases by 1.19 percentage points. However, when inflation exceeds its threshold, it has a negative effect on growth. For non-resource rich countries also, the estimated inflation threshold value $(9.4 \%)$ is certainly less than in resource rich countries. The coefficient of inflation is significantly negative when inflation exceeds its threshold value, clearly suggesting a growth-reducing effect of excessive inflation for resource-rich countries. 
This study found an inflation threshold of 11.1 percent for Africa. This finding is in line with Nell (2000) which suggests that single-digit inflation may be beneficial to growth, while double digit may slow growth. The finding is comparable to the statistically significant thresholds of 11-12 percent found by Khan and Senhadji (2001) for developing countries. This finding is further comparable to the $10 \%$ threshold level of inflation for GDP growth found by Espinoza et al. (2010) for a panel of 165 countries. Pollin and Zhu (2005) also found a threshold inflation in the range of $15-23$ percent for low-income countries. Frimpong and Oteng-Abayie (2010) found an inflation threshold of 11 percent for Ghana.

Consistent with the monetarist's quantity theory and the $A D$ and $A S$ curves which suggest an initial positive relationship between inflation and growth which turns negative in the later part, this study shows that inflation distorts long-term growth in Africa if it gets above its threshold value. In Dornbusch et al., (1996), the initial positive relationship between inflation and economic growth is attributable to the time inconsistency problem which lures the producers into more output. It has also been attributed to firms' collusion to supply on agreed price, leading the firm to produce even at higher price (Blanchard and Kiyotaki, 1987). The high and unpredictable inflation rates can be harmful to any economy, as they increase inefficiencies, and prevent long-term planning.

\section{CONCLUSION}

This study has furnished new evidence on the non-linear effects of inflation on long-term growth, as well as the thresholds at which inflation distorts growth in Africa. Using Kremer et al.'s (2013) dynamic panel threshold model, this study establishes that inflation distorts long-term growth in Africa if it gets above its threshold value. This study finds that the estimated inflation threshold for Africa is 11.1 percent. While inflation below this threshold may have some growth-augmenting effects, the evidence clearly suggests a growth-stifling effect of high inflation beyond this threshold for African countries.

However, the results differ for resource-rich and non-resource rich African countries in terms of both the estimated inflation threshold and inflation effects in the different inflation regimes. In resource-rich countries, inflation is beneficial for growth when inflation is below its threshold value. However, when inflation exceeds its threshold, it has a negative effect on growth. The results for non-resource rich countries differ from resou- 


\section{Kelikume}

rce-rich countries estimates in one aspect, the estimated inflation threshold value is certainly less than in resource rich countries. However, the evidence clearly suggests a growth-reducing effect of excessive inflation for both resource-rich and non-resource rich African countries.

\section{IMPLICATIONS}

While the monetarists' quantity theory has suggested that inflation is a monetary phenomenon and much of the literature has suggested a growth-stifling effect of high inflation beyond a particular threshold (e.g., Khan and Senhadji, 2001; Pollin and Zhu, 2005; Espinoza et al, 2010; Frimpong and Oteng-Abayie, 2010; Rutayisire, 2013), this study has expanded the literature on the relationship between inflation and economic growth in Africa and has provided new insights into the relations between the two variables in the long term. This study finds that the estimated inflation threshold for Africa is 11.1 percent. Inflation below this threshold may have some growth-augmenting effects, while beyond this threshold, inflation may have growth-stifling effects. The inflation threshold of 11.1 percent as well as the marginal effects of inflation on growth strongly suggests that there is a strong need for intensified efforts in terms of inflation targeting in many African countries such as Ghana, Nigeria and Zimbabwe where the current inflation rates are far above this threshold.

Further, the empirical results indicate that the inflation threshold differs for resource-rich and non-resource rich African countries in terms of both the estimated inflation threshold and inflation effects in the different inflation regimes. The results show that the estimated inflation threshold value is certainly less than in resource-rich countries. This indicates that the inflation threshold is higher in resource-rich countries. The higher inflation threshold is a result of movements in resource prices. The implication is that policymakers and business leaders in such countries should monitor resource prices in order to tackle inflation. This is especially necessary in resource-rich countries such as Nigeria where prices of commodities rise and fall with variations in the price of crude oil in the global market.

\section{LIMITATIONS AND FUTURE DIRECTIONS}

The analysis of the threshold relationship between inflation and growth in this study is limited in ways that 
International Journal of Management, Economics and Social Sciences

future studies can perhaps explore. Future research could extend the findings of this study by incorporating more variables that can influence the relationship between inflation and growth. Cutting-edge causality tests would also show how the presence of these variables could affect the outcomes and the associated analyses. Further, extending this study to all the developing countries in Asia, the Caribbean and South America may provide a better understanding of the threshold relationship between inflation and growth and the implications for developing countries in general. Notwithstanding the limitations, the findings of this study are enriching.

\section{REFERENCES}

Ahmed, S. \& Mortaza, M. G. (2005). Inflation and economic growth in Bangladesh: 1981-2005, Working Paper Series: WP 0604,

Research Department, Bangladesh Bank, Dhaka, Bangladesh.

Arellano, M. and Bover, O. (1995). Another look at the instrumental variables estimation of error-components models, Journal of Econometrics, 68, 29-51.

Ball, R. J. (2017). Inflation and the Theory of Money. Routledge.

Bhatia, R. J. (1960). Inflation, deflation, and economic development. Staff Papers, 8(1): 101-114.

Barro, R. J. (1995). Inflation and economic growth, National Bureau of Economic Research (NBER). Working Paperno: 5326.

Blanchard, O. J. \& Kiyotaki, N. (1987). Monopolistic competition and the effects of aggregated demand. American Economic Review, 77(4): 746-66

Blanchard, O., Dell Ariccia, G. \& Mauro, P. (2010). Rethinking macroeconomic policy. Revista de Economía Institucional, 12(22): 61-82. Bruno, M. \& Easterly, W. (1995). Could inflation stabilization be expansionary? Transition, 1(7-8): 1-3.

Bruno, M. \& Easterly, W. (1998). Inflation crises and long-run growth. Journal of Monetary Economics, 41(1): 3-26.

Caner, M. \& Hansen, B. E. (2004). Instrumental variable estimation of a threshold model. Econometric Theory, 20(5): 813-843.

Cuaresma, J. C. \& Silgoner, M. A. (2004). Growth effects of inflation in Europe: How low is too low, how high is too high? (No. 0411). University of Vienna, Department of Economics.

David, D. Pedro, G. P. \& Paula, H. E. (2005). Threshold effects in the relationship between inflation and growth: A new panel-data approach. MPRA paper.

Debaere, P. \& Debaere, P. (2017). Zimbabwe: Grappling with hyperinflation. Darden Business Publishing Cases, 1-15.

Dornbusch, R., Fischer, S. \& Kearney, C. (1996). Macroeconomics. The Mc-Graw-Hill Companies, Inc. Sydney.

Eggoh, J. C. \& Khan, M. (2014). On the nonlinear relationship between inflation and economic growth. Research in Economics, 68(2): 133-143.

Espinoza, R. Hyginus, L. \& Ananthakrishnan, P. (2010). Estimating the inflation-growth Nexus-A Smooth Transition Model IMF Working Paper.

Evans, O. (2018). Money, inflation and output in Nigeria and South Africa: Could Friedman and Schwartz be right? Journal of African Business. In Press.

Foster, N. (2006). Exports, growth and threshold effects in Africa, Journal of Development Studies 42(6): 1056-1074.

Friedman, M. (2017). Quantity theory of money. The new Palgrave dictionary of economics, 1-31.

Frimpong, J. M. \& Oteng-Abayie, E. F. (2010). When is inflation harmful? Estimating the threshold effect for Ghana. American Journal of Economics and Business Administration, 2(3): 225-232.

Ghosh, A. \& Phillips, S. (1998). Warning: Inflation may be harmful to your growth. Staff Papers, International Monetary Fund, $672-710$.

Ghura, D. \& Pattillo, C. (2012). Macroeconomic policy frameworks for resource-rich developing countries; IMF Policy Paper; August 24, 2012.

Gillman, M. Harris, M. \& Mátyás, L. (2002). Inflation and growth: Some theory and evidence. 10th International Conference on Panel Data, Berlin, July 5-6, 2002 D5-1. 


\section{Kelikume}

Gokal, V. \& Hanif, S. (2004). Relationship between Inflation and Economic Growth, Economics Department, Reserve Bank of Fiji, Suva, Fiji, Working Paper.

Goncalves, C. E. S. \& Salles, J. M. (2008). Inflation targeting in emerging economies: What do the data say? Journal of Development Economics, 85, 312-318.

Hansen, B. E. (1999). Threshold effects in non-dynamic panels: Estimation, testing, and inference, Journal of Econometrics, 93, 345368.

Hussain, M. (2005). Inflation and growth: Estimation of threshold point for Pakistan, Pakistan Business Review, 7(3): 1-15.

Kelikume, I. \& Evans, O. (2015). Inflation targeting as a possible monetary framework for Nigeria. The International Journal of Business and Finance Research, 9(5): 71-81.

Khan, M. S. \& Senhadji, A. S. (2001). Threshold effects in the relationship between inflation and growth, IMF Staff Papers, 48(1): 1-21.

Kremer, S. Bick, A. \& Nautz, D. (2013). Inflation and growth: New evidence from a dynamic panel threshold analysis. Empirical Economics, 44(2): 861-878.

LeBlanc, M. \& Chinn, M. D. (2004). Do high oil prices presage inflation? The evidence from G-5 countries. UC Santa Cruz Economics Working Paper, (561), 04-04.

Li, M. (2006). Inflation and economic growth: Threshold effects and transmission mechanisms. Department of Economics, University of Alberta, 2(5): 8-14.

Munir, Q. Mansur, K. \& Furuoka, F. (2009). Inflation and economic growth in Malaysia: A threshold regression approach, ASEAN Economic Bulletin, 26(2): 180-193.

Nas, T. F. \& Perry, M. J. (2018). Turkish inflation and real output growth: 1963-2000. In Inflation and Disinflation in Turkey (pp. 145-160). Routledge.

Ndou, E. \& Gumata, N. (2017). Inflation dynamics in South Africa: The role of thresholds, exchange rate pass-through and inflation expectations on policy trade-offs. Springer.

Nell, K. S. (2000). Is low inflation a precondition for faster growth? The case of South Africa. Working Paper, 7.

Nkume, J. B. \& Ngalawa, H. (2014). Optimal inflation threshold for economic growth in Malawi. Journal of Economics and Behavioral Studies, 6(12): 933-946.

Pindiky, R. S. \& Solimano, A. (1993). Economic instability and aggregate investment. NBER Macroeconomics Annual, 8, $259-303$.

Pollin, R. \& Zhu, A. (2005). Inflation and economic growth: A cross-country non-linear analysis. Working Paper Series No.109, PERI, University of Massachusetts Amherst.

Rossouw, J. \& Marais, M. (2018). The Phillips curve revisited: Implications of an urban legend for economics teaching in South Africa. Southern African Business Review, 22(1): 1-17.

Rutayisire, M. J. (2013). Threshold effects in the relationship between inflation and economic growth: Evidence from Rwanda. A paper submitted to African Economic Research Consortium (AERC). Retrieved on Monday 27 from https://editorialexpress.com/cgi bin/.../download.cgi.

Salami, D. \& Kelikume, I. (2010). An estimation of inflation threshold for Nigeria (1970-2008). International Review of Business Research Papers, 6(5): 375-385.

Sweidan, O. D. (2004). Does inflation harm economic growth in Jordan? An econometric analysis for the period 1970-2000, International Journal of Applied Econometrics and Quantitative Studies, 1(2): 41-66.

Tobin, J. (1965) Money and economic growth, Econometrica, 33, 671-684.

Uysal, G. (2016). Golden quantity theory: Against monetarist school. Economics, 4(3): 135-137.

Vinayagathasan, T. (2013). Inflation and economic growth: A dynamic panel threshold analysis for Asian economies. Journal of Asian Economics, 26, 31-41.

The World Bank, World Development Indicators (2017). Inflation [Data file]. Retrieved from https://data.worldbank.org/indicator/FP.CPI. TOTL.ZG.

Yabu, N. \& Kessy, N. J. (2015). Appropriate threshold level of inflation for economic growth: Evidence from the three founding EAC countries. Applied Economics and Finance, 2(3): 127-144. 
Appendix-I

\begin{tabular}{|c|c|c|c|c|c|}
\hline Country & $\eta_{\text {mean }}$ & $D G D P_{m e a n}$ & Country & $\eta_{\text {mean }}$ & $D G D P_{\text {mean }}$ \\
\hline Algeria $^{*}$ & 8.46 & 1.68 & Mali $^{*}$ & 4.02 & 2.26 \\
\hline Benin & 3.35 & 2.53 & Mauritania & 5.85 & 0.27 \\
\hline Botswana* & 8.34 & 6.53 & Morocco* & 4.26 & 2.65 \\
\hline Burkina Faso & 3.82 & 1.55 & Mozambique & 33.84 & 3.61 \\
\hline Burundi* $^{*}$ & 7.85 & 1.09 & Namibia $^{*}$ & 9.48 & 0.68 \\
\hline Cameroon ${ }^{*}$ & 5.92 & 1.43 & Niger & 4.50 & 0.94 \\
\hline Cape Verde & 5.86 & 5.14 & Nigeria ${ }^{*}$ & 13.35 & 1.07 \\
\hline $\begin{array}{l}\text { Central } \\
\text { African } \\
\text { Republic }^{*}\end{array}$ & 4.54 & 0.16 & Rwanda & 8.03 & 2.26 \\
\hline Chad $^{*}$ & 2.50 & 1.18 & Senegal & 4.98 & 0.18 \\
\hline Congo & 6.12 & 1.68 & Sierra Leone* & 31.63 & 0.16 \\
\hline Cote d'Ivoire & 5.55 & 0.79 & South Africa ${ }^{*}$ & 6.86 & 1.65 \\
\hline Egypt $^{*}$ & 7.26 & 3.47 & Sudan* & 36.42 & 0.54 \\
\hline $\begin{array}{l}\text { Equatorial } \\
\text { Guinea* }^{*}\end{array}$ & 10.08 & 13.15 & Swaziland & 9.85 & 3.07 \\
\hline Ethiopia & 4.98 & 2.02 & Tanzania* & 15.41 & 1.89 \\
\hline Gabon* & 4.88 & 0.34 & Togo & 5.42 & 0.51 \\
\hline Gambia & 8.06 & 1.14 & Trinidad \& Tobago & 6.10 & 3.97 \\
\hline Ghana* & 27.54 & 8.20 & Tunisia $^{*}$ & 3.99 & 3.65 \\
\hline Guinea-Bissau & 20.65 & 1.56 & Uganda & 41.01 & 1.82 \\
\hline Kenya & 8.15 & 0.34 & Zambia $^{*}$ & 28.54 & 0.25 \\
\hline Lesotho & 10.34 & 3.90 & Zimbabwe* & 29.68 & 0.65 \\
\hline Malawi & 15.88 & 1.51 & & & \\
\hline
\end{tabular}

Table 1: Sample of African Countries 


\section{Kelikume}

Appendix-II

\begin{tabular}{|c|c|}
\hline$X$ & $\begin{array}{c}\text { Vector of control variables (INITIAL, IGDP, DPOP, DTOT, SDTOT, OPEN, } \\
\text { SDOPEN) }\end{array}$ \\
\hline$\eta$ & Five-year average of the annual percentage change of the CPI index \\
\hline$D G D P$ & Five-year average of the annual growth rate of real GDP per capita \\
\hline INITIAL & Lagged five-year average of GDP per capita in logs \\
\hline$I G D P$ & Five-year average of the annual percentage of GDP dedicated to investment \\
\hline OPEN & $\begin{array}{l}\text { Logged five-year average of openness (proxied as the share of exports plus imports in the } \\
\text { GDP) }\end{array}$ \\
\hline$S D O P E N$ & Five-year standard deviation of openness \\
\hline DTOT & $\begin{array}{c}\text { Five-year average of the annual percentage change in the terms of trade (proxied as exports } \\
\text { divided by imports) }\end{array}$ \\
\hline SDTOT & Five-year standard deviation of the terms of trade \\
\hline$D P O P$ & Five-year average of the annual growth rate of population \\
\hline
\end{tabular}

Table 2: List of Variables 


\begin{tabular}{|c|c|c|c|}
\hline Threshold Estim & $\begin{array}{l}\text { Full Sample of African } \\
\text { Countries }\end{array}$ & Resource Rich Countries & Non-resource Rich Countries \\
\hline$\hat{\tau}$ & 11.074 & 12.681 & 9.405 \\
\hline $\begin{array}{l}95 \% \text { confidence } \\
\text { interval }\end{array}$ & {$[6.393,15.025]$} & {$[8.840,14.992]$} & {$[6.653,11.197]$} \\
\hline \multicolumn{4}{|c|}{ Impact of inflation } \\
\hline$\hat{\alpha}_{1}$ & $\begin{array}{l}1.216^{* *} \\
(0.699)\end{array}$ & $\begin{array}{l}1.190^{* * *} \\
(0.605)\end{array}$ & $\begin{array}{l}1.248 \\
(0.792)\end{array}$ \\
\hline$\hat{\alpha}_{2}$ & $\begin{array}{l}-0.877^{* *} \\
(0.481)\end{array}$ & $\begin{array}{l}-0.483^{*} \\
(0.219)\end{array}$ & $\begin{array}{l}-0.507^{* *} \\
(0.282)\end{array}$ \\
\hline \multicolumn{4}{|c|}{ Impact of covariates } \\
\hline$I N I T I A L_{i t}$ & $\begin{array}{l}-1.798^{* *} \\
(0.994)\end{array}$ & $\begin{array}{l}-2.539^{*} \\
(1.173)\end{array}$ & $\begin{array}{l}-2.662^{*} \\
(1.155)\end{array}$ \\
\hline$I G D P_{i t}$ & $\begin{array}{l}0.997^{*} \\
(0.125)\end{array}$ & $\begin{array}{l}0.086 \\
(0.027)\end{array}$ & $\begin{array}{l}0.790^{* *} \\
(0.029)\end{array}$ \\
\hline$D P O P_{i t}$ & $\begin{array}{l}0.497 \\
(0.270)\end{array}$ & $\begin{array}{l}0.093 \\
(0.359)\end{array}$ & $\begin{array}{l}0.108 \\
(0.377)\end{array}$ \\
\hline$D T O T_{i t}$ & $\begin{array}{l}-0.607 \\
(0.249)\end{array}$ & $\begin{array}{l}-0.039 \\
(0.099)\end{array}$ & $\begin{array}{l}-0.541 \\
(0.093)\end{array}$ \\
\hline$S D T O T_{i t}$ & $\begin{array}{l}-0.259 \\
(0.095)\end{array}$ & $\begin{array}{l}-0.053 \\
(0.015)\end{array}$ & $\begin{array}{l}-0.705 \\
(0.058)\end{array}$ \\
\hline$O P E N_{i t}$ & $\begin{array}{l}1.325^{*} \\
(3.190)\end{array}$ & $\begin{array}{l}1.265^{* *} \\
(3.079)\end{array}$ & $\begin{array}{l}1.026^{* *} \\
(3.228)\end{array}$ \\
\hline$S D O P E N_{i t}$ & $\begin{array}{l}1.511^{*} \\
(0.559)\end{array}$ & $\begin{array}{l}0.266^{* * *} \\
(0.174)\end{array}$ & $\begin{array}{l}0.879^{* * *} \\
(0.498)\end{array}$ \\
\hline$\hat{\beta}_{1}$ & $\begin{array}{l}-0.681 \\
(0.870)\end{array}$ & $\begin{array}{l}-0.564 \\
(0.511)\end{array}$ & $\begin{array}{l}-0.291 \\
(0.383)\end{array}$ \\
\hline Observations & 1435 & 903 & 740 \\
\hline $\mathrm{N}$ & 41 & 21 & 20 \\
\hline $\mathrm{R}^{2}$ & 0.99 & 0.99 & 0.97 \\
\hline
\end{tabular}

Table 4: Inflation Thresholds and Long-Term Growth in Africa 